\title{
Imagining the Future: Children, Education and Intergenerational Transmission of Poverty in Urban Bangladesh
}

\author{
Naila Kabeer and Simeen Mahmud
}

\begin{abstract}
Failure to invest in children's education is widely recognised as a key mechanism for the intergenerational transmission of poverty. At the same time, rising levels of education among different socioeconomic groups in countries like Bangladesh suggest that poverty on its own is not an adequate explanation for this failure. This article uses survey data on low-income households in urban Bangladesh to explore what differentiates parents who have managed to send their children to school from those who have not. One factor is education: parents with no education are more likely to have children of schoolgoing age who are not at school. Different aspects of household vulnerability, as captured by asset deficits, reliance on casual labour and female headship, also play an important role in determining whether children go to school or not. In addition, the article argues that contextual factors have an important influence on how parents imagine their children's future and how children themselves regard education. The hazards of daily life in slum environments, the limited range of job opportunities available and the absence of decent educational facilities all serve to undermine parental commitment and children's motivation with regard to education. The article suggests that the state and civil society should collaborate to promote educational and livelihood interventions which are responsive to the needs of the more vulnerable sections of the poor and to reshape how parents and children envisage the future.
\end{abstract}

\section{Intergenerational contracts and the quantity-quality transition}

The concern of this article is with the intergenerational transmission of poverty, a particular manifestation of chronic poverty (Hulme et al. 2001). Chronic poverty is defined by its extended duration. It does not necessarily describe the same phenomenon as extreme poverty but it is highly probable that many chronically poor people are also likely to be extremely poor: the severity and intractability of deprivation are likely to go hand in hand. The transmission of poverty across generations occurs through the transmission of various kinds of deficit. In contexts where poor people rely primarily on the sale of their labour power to meet survival needs, the failure to invest in the 'human capital' of successive generations, their education and skill, is likely to be a common route through which the intergenerational transmission of poverty occurs. While investments in human capital can, in principle, occur at any stage of the individual life course, in practice, investments undertaken during childhood have critical implications for subsequent life chances. In most societies, parents continue to play a critical role in determining the nature of these investments.

The idea of the 'quantity-quality' trade-off in family formation strategies (Becker and Lewis 1973) makes the logical point that, given resources constraints, there is a trade-off between the number of children within a family and investments in their human capital. This tradeoff provides a link between increasing investments in children's education and broader processes of demographic transition and the shift

IDS Bulletin Volume 40 Number 1 January 2009 (c) 2009 The Author(s). Journal compilation (c) Institute of Development Studies Published by Blackwell Publishing Ltd, 9600 Garsington Road, Oxford OX4 2DQ, UK and 350 Main Street, Malden, MA 02148, USA 
from high to low fertility regimes. Historical evidence suggests that large-scale declines in fertility rarely take place till there has been a decline in mortality. It also confirms that declines in fertility have been accompanied in many parts of the world by rising levels of education (Montgomery et al. 1999; Kabeer 1996).

In an earlier paper (2001), Kabeer sketches out a stylised account of the changing nature of the implicit intergenerational contracts between parents and children in the context of demographic change that might help to explain the 'quantity-quality' transition in family formation strategies. This included an 'affective transition', the greater willingness on the part of parents to invest emotionally in each individual child as initial, largely 'exogenous', declines in mortality increased the likelihood that children would survive beyond the first precarious years of life (Stone 1977; Scheper-Hughes 1992). A second shift related to the greater sense of personal agency that parents are able to exercise in relation to family formation strategies as more effective means for assuring both child survival and birth control become available to them (Cleland and Wilson 1987). This has been variously described as part of a larger transition from 'accommodation' to 'intervention' and by Gleland and Wilson (1987) 'from fatalism to a sense of control of destiny'. As Montgomery (1999: 20) points out, this does not necessarily suggest that a sense of agency is absent in highmortality, pre-transitional societies, but rather that the scope for strictly personal agency is much more limited.

A decline in mortality can lead to fertility decline at the very minimum because it reduces the 'insurance motivation' for having children; in other words, having enough children to ensure that a certain number (sometimes of the preferred sex) will survive to adulthood. Other factors which accompany declining mortality may further strengthen the desire for fertility control. Similarly the availability of effective means of birth control can act to hasten the speed of fertility decline through a number of different pathways: changes in the wider society which reduce the 'benefits' or increase the 'costs' of large family size and, some have argued, because it brings the fertility decision within the 'calculus of conscious choice' (Cleland and Wilson 1987).
As child survival becomes increasingly assured, as parents begin to take an active role in how many children they have rather than leaving it to fate or divine will, a different form of decision-making becomes possible, 'one that involves forwardlooking strategies that play out over longer time horizons' (Montgomery 1999: 12). A transition in time horizons permits the consideration of new forms of investment in children which might not have previously featured as possible options, even at the level of imagination.

Particularly for those close to the margins of survival, education exemplifies an investment which entails considerable risk. It requires families to sacrifice current consumption in favour of future returns. In an uncertain world, it represents a statement of faith about the future: about what the future will bring, about which children will survive to take advantage of it, and about their willingness to fulfil their obligations to the generation that made the sacrifice. Smaller family sizes make such investments more affordable. The 'quantity-quality' transition has thus been described as transition from family-building by fate to family-building by design (Lloyd and Ivanov 1988).

There is, as Montgomery points out, nothing automatic or self-propelling about these transitions. It may be one or more generations before declines in mortality give rise to declines in fertility and a further delay before parents become more willing to invest in their children's education. Context matters for the pace of these transitions:

In the most basic sense, some level of development is required before family size can have an impact on child investment. In an environment without schools or clinics, parents have few ways to materially influence their children's health or schooling, whether their resources are spread among many or few. (Lloyd 1994; see also Desai 1993)

Parents' assessments of potential returns to investments in health or education will partly depend on the quality of health and educational services available and partly on likely opportunities in the labour market (Lloyd 1994: 9 ). What appears to be key therefore is the likelihood that the fertility transition will be accompanied, or followed, by rising levels of investment in children's education. 


\section{Exploring the quantity-quality transition in Bangladesh}

Evidence suggests that a quantity-quality transition is in process in Bangladesh. Declines in child mortality and fertility have occurred in recent decades as part and parcel of larger social and economic change, including the spread of the cash economy, the productivity gains of the Green Revolution, increased ease of communications and transport, the growing importance of the media, and the proliferation of contract-based relationships in place of previous personalised patron-client ones. All of these have directly or indirectly increased the value attached to the acquisition of basic levels of information and knowledge, particularly in the context of engagement with markets and services, and are likely to have contributed to a remarkable rise in children's education, including girls' education, at the national level.

However, the pace of change has not been uniform across the population. It has been slower in poorer districts of Bangladesh and among poorer households. At the same time, it is clear that poverty is not an insurmountable barrier to children's education and that many children from low-income households do go to school (see overview in Kabeer 2003). The relationship between household poverty and children's education appears to be mediated by a variety of factors, including the child's age and gender, household livelihood strategies, parental education and the availability and quality of schooling. Severity of deprivation may also matter. Participatory Rural Appraisal (PRA) explorations in rural Bangladesh suggest that the very poor may have different priorities and operate with different understandings of intergenerational contracts from moderately poor households. The very poor described their most pressing needs in terms of three meals a day, adequate housing and basic healthcare, while the moderately poor specified concrete housing, comprehensive health services and education as their priorities (Hamid 1998). The significance attached to education was thus one of the factors which distinguished the poor from the very poor.

If failure to invest in children's education is, indeed, one of the forces driving the intergenerational transmission of poverty, and if poverty itself is one of the factors behind this
Table 1 Parents' different expectations of sons and daughters in urban Bangladesh

\begin{tabular}{lll}
\hline & Sons & Daughters \\
\hline Financial dependence & $92 \%$ & $19 \%$ \\
Social dependence & $78 \%$ & $87 \%$ \\
Ideal education: primary & $9 \%$ & $32 \%$ \\
Ideal education: secondary & $41 \%$ & $45 \%$ \\
Ideal education: higher & $17 \%$ & $10 \%$ \\
Graduate & $32 \%$ & $10 \%$
\end{tabular}

failure, we need a better understanding of the relationship between household poverty and children's education. The aim of this article is to revisit the idea of intergenerational contracts as a framework for understanding the uneven pace of the quantity-quality transition in the context of urban Bangladesh. The analysis here draws on quantitative data gathered through a household survey carried out in 2001 in two slum neighbourhoods (Pallabi and Agargaon) in Dhaka. The survey covered 616 households, roughly evenly divided between the two neighbourhoods. A sub-component of the survey was addressed to all children aged 5-15 in these households; this covered 297 households. Qualitative data was subsequently gathered through in-depth interviews and focus group discussions with parents, children and teachers.

\section{Intergenerational contracts and children's education: findings from urban Bangladesh} As a first stage of the research, we explore the evidence for the persistence of intergenerational contracts in our sample population. Table 1 suggests that parents continue to have certain expectations of support from their children. They have high expectations of financial and social support from sons and high expectations of social but not financial support from daughters. The picture in relation to financial expectations reflects the reality of a culture that privileges men, and constrains women, in access to material resources, income and opportunities. We find similar gender asymmetries expressed in relation to ideal education levels for sons and daughters, with higher educational ideals expressed in relation to sons. There is not a great deal of difference in these expressions of expectations from children and obligations towards children by age of parent. 
Table 2 Age distribution of study population by school attendance and labour force participation in Pallabi and Agargaon

\begin{tabular}{|c|c|c|c|c|c|c|c|c|c|c|}
\hline \multirow[t]{2}{*}{ Age } & \multicolumn{2}{|c|}{$\begin{array}{l}\text { Ever went to } \\
\text { school (\%) }\end{array}$} & \multicolumn{2}{|c|}{$\begin{array}{c}\text { Currently in } \\
\text { school (\%) }\end{array}$} & \multicolumn{2}{|c|}{$\begin{array}{c}\text { Engaged in } \\
\text { income work (\%) }\end{array}$} & \multicolumn{2}{|c|}{$\begin{array}{c}\text { Engaged in } \\
\text { wage work (\%) }\end{array}$} & \multicolumn{2}{|c|}{$\begin{array}{l}\text { Age at first work } \\
\text { (mean years) }\end{array}$} \\
\hline & Male & Female & Male & Female & Male & Female & Male & Female & Male & Female \\
\hline \multicolumn{11}{|l|}{ Pallabi } \\
\hline 5-15 & 70 & 76 & 54 & 57 & 10 & 18 & 9 & 16 & 12.4 & 12.1 \\
\hline $16-49$ & 67 & 53 & 5 & 3 & 89 & 47 & 67 & 47 & 16.1 & 19.1 \\
\hline $50+$ & 43 & 19 & - & - & 80 & 22 & 59 & 13 & 17.2 & 29.0 \\
\hline All ages & 58 & 51 & 15 & 16 & 59 & 32 & 45 & 31 & 16.2 & 19.1 \\
\hline \multicolumn{11}{|c|}{ Agargaon } \\
\hline 5-15 & 75 & 76 & 62 & 63 & 12 & 11 & 8 & 11 & 10.6 & 17.3 \\
\hline $16-49$ & 38 & 20 & 1 & 0 & 95 & 38 & 21 & 33 & 15.8 & 21.2 \\
\hline $50+$ & 33 & 0 & - & - & 88 & 40 & 20 & 29 & 16.6 & 26.4 \\
\hline All ages & 40 & 29 & 15 & 15 & 59 & 25 & 14 & 22 & 15.8 & 21.7 \\
\hline
\end{tabular}

However, an examination of percentages of children who had ever been to school by age cohort of the population suggests that there has been a change over time (Table 2). Percentages of children ever enrolled are higher and gender disparities have all but disappeared in the younger cohorts, echoing rising education levels and declining gender disparities in the national data (Kabeer 2003). It is also evident that everenrolled figures overstate the extent of change. Comparison of estimates in the 5-15 age group suggest that current enrolment rates are much lower than ever-enrolled rates, indicating that dropout rates remain high: while around 70 per cent of children were ever enrolled in school, only $50-60$ per cent of children are currently going to school. A further disaggregation of this age group shows that most of these dropouts occur in the 13-15 age group when, presumably, children are old enough to be sent to work or to help out around the house. The table also shows that around 10-20 per cent of children are engaged in waged work. Most of these are from the out-of-school category.

Our findings, therefore, suggest uneven changes in intergenerational contracts. Against a background of rising levels of education in younger age cohorts, our sample is divided into parents who have managed to send and keep their children in school and parents who have either failed to enrol their children at school or failed to keep them there. Interviews with parents in the former category provide some insights into why parents are increasingly redefining their obligations to their children to include investments in their education. There was widespread acknowledgement that education had increased in value over time to the extent that it was now a necessity. As one parent put it:

\section{Is there anything possible today without an education? You need to be educated if you go for a job in any garment factory, if you want to start a business and even if you want to set up a shop. You need education when you walk on the streets of Dhaka city: what is written on this sign says and what is written on that sign. What number stands for what, looking for a house, finding a place.}

However, the value of education was interpreted differently for sons and daughters. For sons, it was closely linked to their occupational choices, to getting a job that would command status and money in the world and which might predispose them to looking after their parents in their old age. For daughters, education would prepare them for their role in a society where what was expected of wives and mothers was undergoing a change. In addition, some mothers believed that it would equip their daughters with the ability to stand on their own feet should their marriages break down or their husbands prove unreliable. 
Table 3 Household vulnerability and educational deficits

\begin{tabular}{llll}
\hline & $\begin{array}{l}\text { Children } \\
\text { not at } \\
\text { school }\end{array}$ & $\begin{array}{l}\text { Children } \\
\text { at school }\end{array}$ & Significance \\
\hline O-1 assets & $55 \%$ & $45 \%$ & .000 \\
$2-4$ assets & $33 \%$ & $67 \%$ & \\
\hline $\begin{array}{l}\text { Casual labour } \\
\text { households (hhs) }\end{array}$ & $44 \%$ & $56 \%$ & .047 \\
$\begin{array}{l}\text { Other hhs } \\
\text { Female-headed }\end{array}$ & $67 \%$ & $33 \%$ & .000 \\
hhs & & $63 \%$ & \\
\hline $\begin{array}{l}\text { Male-headed hhs } \\
\text { The }\end{array}$ & $38 \%$ & $63 \%$ & \\
\hline
\end{tabular}

* Significance indicates the level of confidence we can have in the results. In the statistical analysis for this article, we have only reported on differences between groups which were significant at at least $10 \%$ level of confidence.

This kind of reasoning explained why, despite their poverty, many parents had struggled to send and keep their children in school. At the same time, there is a sizeable sample of parents whose children either had never enrolled in school or had dropped out of school. Presumably, this second group of parents either did not subscribe to these changing values about education or else were unable to act on them. In the rest of this article, we examine these two groups in greater detail. We use our quantitative data to ascertain how they differ from each other and our qualitative data to interpret these quantitative differences and to explore in greater detail how they might lead to differences in intergenerational contracts between the two groups. Some of these differences are statistically significant and offer causal insights into the pattern of educational deficits.

\subsection{Household vulnerability and educational deficits}

Within the urban slum contexts where the majority of households were poor, our data suggests that it was vulnerabilities of various kinds that explained differences in children's educational outcomes. As Chambers (1989) points out, the concept of vulnerability encompasses both 'external' and 'internal' dimensions. The external dimension refers to the likelihood of shocks and stresses faced by households, both idiosyncratic to specific households and those that are generalised across households. The internal dimension, on the other hand, refers to the capacity of different households to cope with these threats to their livelihoods and standard of living. Table 3 captures some of the differences in the capacity to cope between households whose children were at school and those where they were not. It suggests that children were less likely to go to school in households which did not own any assets, which relied on causal labour as their primary source of livelihood or which were headed by women.

Our research material suggests that different kinds of vulnerability tend to overlap. Thus, casual labour households were vulnerable, in the first instance, because of the irregularity and unpredictability of their income flows. Their mean income levels were lower than households reliant on other kinds of occupations, and they were less likely to report a surplus at the end of the month. Their members generally earned on a daily basis and did not always know if and how much they would earn on a particular day. What they ate each day depended on what they earned each day. One husband and wife who worked together in a brickfield earned on a literally 'brick-by-brick' basis: they were paid Tk35 for every hundred bricks so that their earnings varied by the number of bricks they managed to break between them and the number of days they managed to find work.

In addition, casual labour households were also vulnerable because they lacked some of the other resources that could help them to cope with the stresses and strains that were a routine part of their lives. Such households owned fewer assets than other households in our sample, were less likely to report a surplus at the end of the month, less likely to have access to formal sources of loans or affiliations with non-governmental organisations (NGOs) and less likely to have savings.

Female-headed households were also characterised by overlapping forms of disadvantage. They also had lower levels of assets, were less likely to report a surplus at the end of the month, were less likely to have savings or access to formal sources of loans and were less likely to be affiliated to a formal civil society organisation. However, their economic vulnerability did not necessarily stem from the casual nature of their work: many worked in garment factories or domestic work and were less 
reliant on casual labour as their main source of income than male-headed households. Instead, their vulnerability was a product of gender-related disadvantage.

Many female household heads were divorced or deserted. Jesmin and Salway (2000) talks about 'serial monogamy' to describe the marital behaviour of men in his study of a Dhaka bastee (slum neighbourhood). The marriage patterns captured by our qualitative research suggested a much greater diversity: some men left their wives and were never seen again, others contracted polygamous marriages, others remarried but then returned for a while, contributed to the marriage or expected their wives to support them and then left again. Thus, female headship was generally an indicator of some form of marital crisis which had left the wife to fend for herself and her children. Such forms of crisis were usually associated with an abrupt drop in household income. Most female household heads were, therefore, primary breadwinners for their households in a society in which gender confined women to a far more limited set of income-earning opportunities than men. Most did not have any adult male members in the household who could have earned, or shared the burden of earning, the household livelihood. Their mean incomes were not only lower than those of male-headed households but also lower than levels reported by other assetless and casual labour households.

Anxiety about the future clearly had an objective basis in reality for the more vulnerable households within slum neighbourhoods, given the variety of threats to which they were exposed and the fragility of their household resource base. In addition, for those who were engaged in a constant struggle to keep their heads above water, there was a strong subjective dimension to their experience of vulnerability which limited their ability to think ahead and plan for the future. This was evident from the response given by Shahjahan, a rickshaw puller who was asked why he did not send his children to the free government school in his locality:

I don't know anything about government free schools, and I have no interest in knowing. My head is so full of so many troubles - how my family can survive and how we can continue? Really, I have no space in my mind to think of schooling for my son, whether it is free or not. Now I am in debt of 12,000 taka. I owe 1,000 taka to the local shop owner, I owe 1,000 taka to a moneylender - he charges 200 taka per month interest until I can pay off the full amount. The other 10,000 taka I owe to a rickshaw salesman. I entered an agreement with this man whereby I pay 50 taka per day until I have paid him the full 10,000 taka, he doesn't charge interest for delayed payment. From the moment I took the rickshaw from him, the rickshaw was mine. But for the last five days I have not been able to pay any money. I need $2 \mathrm{~kg}$ rice per day and the house rent is 500 taka, I haven't been able to pay this for the last three months.

Children from these different categories of vulnerable households were less likely to be enrolled in school - and more likely to drop out because of the 'hand-to-mouth' existence imposed by low and uncertain earnings of their households and the absence of an asset base to fall back on in times of crisis. If the willingness to invest in a child's education requires the capacity to imagine and plan for the future, as discussed earlier in the article, these parents were largely oriented to the present: they had 'no space in their mind' to think about the future when the present was so crowded with demands. They had to discount any form of expenditure which not only failed to meet their immediate needs, but whose benefits were uncertain in terms of what they might be and whether they might ever materialise. Their explanations as to why they did not send their children to school spelt out the harsh nature of the trade-offs they faced:

I have enough brains to know it is good to send the children to school, but what can I do? Can anyone study on an empty stomach? Will they first eat and survive or will they first go to school and study?

\section{My father passed away four years ago. Although I know that it is my duty to provide food for my parents, I was unable to do so. I think that is the reason my father died. I feel I failed him. My other brothers also did not provide any food to our parents. My mother is a beggar now. For a man who cannot even provide his mother with food, tell me, how can he provide school fees for children?}

\subsection{Endemic insecurity and educational deficits}

Our survey data helped us to identify particular categories of vulnerable households who had either failed to enrol their children in school or had failed to keep them enrolled in school. 
However, our qualitative interviews highlighted other kinds of insecurities, which had similar effects. These could not be reduced to specific threats and events but were woven into the stressful fabric of daily life in urban slum neighbourhoods. They partly reflected the physical constitution of these neighbourhoods. Excluded from the safer and higher valued locations in the city, the poor were concentrated in its more precarious sites: its fragile embankments, garbage dumps and areas through which other people's effluent flowed (Wood and Salway 2000). This made them vulnerable to seasonal flooding, landslides and the risk of disease.

Insecurities were also generated by the structure of livelihood opportunities in these neighbourhoods. While the urban informal economy is generally characterised by casual waged and self employment in manufacturing, trade and service activities, urban slum neighbourhoods tend to be sites of various 'antisocial livelihood activities', including theft, drugselling, gambling, professional begging and prostitution, which flourish in slum areas, adding a criminal underground element to the informal economy (Khan 2001).

In addition, insecurities inhered in the social relationships prevailing in slum neighbourhoods. 'Mafia-like' gangs of mastaans (musclemen) acted as intermediaries between slum dwellers and local politicians, businessmen and other powerholders. They also played a central role in the underground economy. As Wood and Salway (2000) put it, they operated like entrepreneurs of a certain kind, exploiting the vulnerabilities of the slum dwellers, on the one hand, and the needs of politicians, officials, private sector business and the middle classes for clients, cheap labour, votes and so on, on the other. They controlled access to housing, to livelihood opportunities, to local amenities, including illegal connections to public utilities through their capacity for brokering patronage or using violence, or the threat of violence.

Violence in the slums has also escalated over the past decade because of the increasingly confrontational nature of national politics; strikes, curfews and political conflicts have become commonplace.
Our qualitative data highlighted the relevance of this wider context in shaping aspirations and behaviour relevant to children's access to education. As one mother's comments indicated, attempts to cope with periodic episodes of violence entailed constant interruptions to children's school attendance:

I do not allow them to go outside when firing and violence takes place. Severe fighting took place a few days ago, full of bombs and gunfire. I stayed in the house with my child keeping the door shut. His father did not come home that night. When my son goes to school, I do not let him go alone. I accompany him. I am afraid for myself too while walking in the street. Yesterday I was passing through this way and heard the bombs blasting. When I feel very insecure, we move away somewhere for a while, leaving this area.

Along with these periodic outbursts of violence, a pervasive state of lawlessness and disorder kept parents in a state of constant anxiety about the safety of their children. Some relied on older children to look after younger ones while they were at work. Others took them to work with them: women working in domestic service were often able to do this. Still others put their children to work: sending young girls to work in domestic service or to factory employment was another way of ensuring their security. Working mothers had particular anxieties about leaving young girls on their own in the house, because of concerns about their sexual safety.

However, parents' anxieties did not only relate to what harm might come to their children but also to what their children themselves might get up to. Children exercised considerable agency in shaping educational outcomes and children described as indifferent to schooling were also more likely to be out of school. Children's interactions with their peers often served to undermine parental wishes. Focus group discussions with fathers described some of the negative influences of life in the slums, which undermined children's ability to study, contrasting it with the greater order and discipline of rural life:

In rural areas, the environment is not so undisciplined, there is no electricity, the children can't go anywhere, they have to sit with their books. Here in the city, children don't come home till after seven.

They just roam around. Those who have never studied, they just play and when they get older, they go into 


\begin{tabular}{|c|c|c|c|}
\hline & $\begin{array}{l}\text { Children not } \\
\text { at school }\end{array}$ & $\begin{array}{l}\text { Children at } \\
\text { school }\end{array}$ & Significance \\
\hline Ideal education for sons: graduate level & $15 \%$ & $85 \%$ & .000 \\
\hline Ideal education for sons: < graduate level & $87 \%$ & $13 \%$ & \\
\hline Ideal education for daughters: graduate level & $12 \%$ & $88 \%$ & .000 \\
\hline Ideal education for daughters: < graduate level & $68 \%$ & $32 \%$ & \\
\hline Aspires to salaried job in future & $20 \%$ & $80 \%$ & .000 \\
\hline Others & $64 \%$ & $36 \%$ & \\
\hline Aspires to garment factory job & $71 \%$ & $29 \%$ & .000 \\
\hline Others & $33 \%$ & $67 \%$ & \\
\hline Child not interested in school & $75 \%$ & $25 \%$ & .000 \\
\hline Child interested in school & $33 \%$ & $67 \%$ & \\
\hline
\end{tabular}

- Significance indicates the level of confidence we can have in the results. In the statistical analysis for this article, we have only reported on differences between groups which were significant at at least $10 \%$ level of confidence.

work, garments or in a shop. There are parents who are just not aware of education, they are not interested in educating their children. Those women who have no husbands, but look after the children on their own, they find it hard to educate their children. Their children may come and go to school but they do not study.

Now the situation is so bad, there is just one film on television after another. Sometimes, we disconnect the $T V$ when we leave the house, but the children manage to reconnect it. If the TV is closed in our house, we can hear everything from next door, their voices, their TV. That is why village is good, no one watches TV hour after hour. The children of the rich don't get spoilt because of TV because there are other forms of help for them, private tutors and so on.

Gender influenced the reasons why children were not at school. Young girls who dropped out of school tended to be influenced by the example of other young girls like themselves who were working for a living, usually in the garment industry, and appeared to enjoy a greater degree of freedom as well as having more money to spend on themselves. They saw little point in going to school:

I wanted my daughter to study till matric, I wanted her to become a nurse but she would not listen to me. She has been living in a bastee and she has got together with others living in the bastee. She has friends who have given up studies, they have all gone to work in the factories. They have made my daughter understand that we are girls from the bastees, what do we need with education?

Boys dropped out to roam the neighbourhood with gangs of other boys like themselves. Female household heads faced particular problems controlling unruly sons: they were more likely to have to go out to work for a living and less likely to have an adult male in the household to impose discipline. One female head had decided that sending her only son away to a madrassah which had residential facilities was the only way to remove him from the influence of the slums. However, male household heads also faced problems maintaining control over sons, particularly if their wives were working. As one father lamented:

Earlier I had sent my eldest son to Rupnagar High School. At that school the admission fee was 160 taka and the tuition fees were 55 taka per month. I paid the money regularly. My wife went to work in a garment factory early in the morning, and I was also working (in my little shop) all day, so neither of us was around to make sure that he went to school. I thought my son was attending school, but then I was told that his admission had been cancelled due to lack of attendance, so that is when I came to know that he hadn't been 
Table 5 Quality and costs of provision and educational deficits

\begin{tabular}{llll}
\hline & Children not at school & Children at school & Significance \\
\hline Perceives education quality to be poor & $62 \%$ & $38 \%$ & .000 \\
Others & $36 \%$ & $64 \%$ & .000 \\
Perceives education to be costly & $94 \%$ & $6 \%$ & $72 \%$
\end{tabular}

going to school. When his admission was cancelled for the second time, I realised it was pointless sending him to school ... I decided it was better if he worked with his mother in the garments factory. He worked there for three months, but then he left. He has not given me an explanation of why he left the factory. I think that my son is a total vagabond.

The importance of values and aspirations as an influence on which children went to school and which did not is evident from Table 4. It tells us that parents who would like their sons and daughters to achieve graduate-level education are more likely to report children in school than those with lower aspirations. Parents who aspire to salaried jobs for their children are more likely to have children attending school while those who intend to send their children into garment factory jobs are less likely to have children at school. Finally, children who express indifference to education are also less likely to be at school.

\subsection{Failures of provision: the 'costs' of education}

For parents facing unruly children, a priority was to find some way of disciplining them. Both work and school offered the possibility of security as well as a measure of discipline. However, here certain aspects of educational provision in the slums militated against the extent to which schools could serve such a role (Table 5). The first related to the perceived quality of education.

Government neglect of the slums had resulted in extremely inadequate forms of provision, in terms of quantity as well as quality. While there was some NGO provision, it was not able to compensate for government failure. As both parents and teachers pointed out, there was more government support for education in rural areas than in urban. Some parents talked about sending their children back to the village for education to take advantage of the food-foreducation scheme and for government stipends. The headmaster of a semi-government school in one of the slums agreed that government neglect played an important role in explaining poor educational outcomes in slum neighbourhoods. Apathy on the part of government led to apathy on the part of teachers as well as various forms of 'unruly behaviour'. Focus group discussions with children elicited a torrent of complaints:

That school is not good, they just want to eat more money ... Rules were good before, but now there are no rules. They used to give students food and books but now they just demand money. Teachers beat students if they are late coming to school ... They tell us to write in the classroom and then they go out for a stroll to the park, to Zia gardens, to parliament buildings ... We go to school at 8am and at 12 o'clock, the teachers come back from the park and say, 'Students, class time is over, go home'. If we cannot read or write, they do not teach us, they just beat us ... If one student cannot read or write, they beat all the students.

The other frequently cited factor was the perceived cost of education. As Table 5 shows, parents who perceived education to be costly were far less likely to enrol children in school than the rest. The household survey suggested that of households with at least one child currently in school, 58 per cent paid annual tuition fees, 54 per cent paid session fees, 54 per cent paid for books and stationery, 33 per cent paid for exam fees, 17 per cent paid towards the child's tiffin (lunch) and 17 per cent paid for a private tutor. These costs are clearly likely to be a deterrent for parents who earn very little and often irregularly. And while only 17 per cent were paying for a private tutor, private tuition was increasingly seen as a prerequisite for getting on in school and for passing exams. One educational practitioner we interviewed referred to the 'phantom private tuition system' that propped up public educational provision, tuition that was recommended and provided by the very teachers who taught them within the public system. Despite all these problems, there was sufficient enthusiasm for 


\begin{tabular}{llll}
\hline & Children not at school & Children at school & Significance \\
\hline Head has no education & $44 \%$ & $56 \%$ & .030 \\
Head has some education & $36 \%$ & $64 \%$ & \\
Spouse has no education & $38 \%$ & $62 \%$ & .066 \\
Spouse has some education & $46 \%$ & $54 \%$ &
\end{tabular}

schooling as a 'social good' expressed during focus group discussions to suggest that committed efforts at community mobilisation by government or NGO to overcome some of these obstacles could pay positive dividends.

\section{Disrupting the intergenerational transmission of poverty: some policy implications}

We suggested at the start of this article that transmission of human capital deficits across generations, exemplified by the failure to invest in children's education, was a major factor driving the intergenerational transmission of poverty. This suggests a degree of path dependence in life trajectories across generations. The children of household heads (but not spouses) who are themselves uneducated are less likely to go to school (Table 6). They are less likely to have worldviews that give value to education or to imagine a life for their children very different from the one that they themselves have had. There are also broader social pressures reinforcing these processes. Children are less likely to go to school when they grow up in communities in which very few children go to school, where the pressure of peers works to discourage school attendance, and where they perceive their own life chances in terms which provide few incentives to go to school.

However, while some degree of path dependence may explain why so many children in the urban slums do not go to school, there is enough evidence from the same slums to suggest that this future was not pre-ordained. We have focused in this article on those parents who failed to send their children to school or failed to keep their children at school. A very different story emerges if we explore the experiences of those parents who managed, despite their poverty, to enrol their children in school and keep them there long enough for them to complete primary and, in some cases, secondary education. There are stories of enormous sacrifices by both parents and children. They testify to the fact that, although the odds are against them, uneducated parents need not necessarily produce uneducated children.

A first set of responses relates to the persistence of educational deficits. A first set of responses relate to ideas and aspirations. It is evident from our findings that parents who aspire to higher education for their children and who imagine a different future for themselves than their own life experiences might have led them to expect are more likely to value education and to ensure that their children go to school. While parents' own education level is one factor in shaping these aspirations, it is not the only factor. Another important factor has been the role of the government. While the government in Bangladesh has largely failed to promote educational opportunities for the urban poor, its campaign to raise public awareness about the value of education appears to have made a difference. Many of the parents we interviewed used the government slogan about illiteracy: 'we have eyes, but we cannot see'. A proactive stance by the government can make a difference because, despite all its failings, the government continues to have a presence and legitimacy in the eyes of the poor that is not matched by other institutions, including NGOs.

A second set of responses relates to the provision of educational services. The greater likelihood that parents with some education are more likely to ensure their children's schooling highlights the importance of educating the current generation of children if the cycle of poverty is to be broken. Simply getting children into schools is only the beginning of the challenge. First-generation learners in a family are known to require a higher level of support and commitment from parents and from teachers. Their parents are not accustomed to the idea that children need to attend school regularly to benefit; that they 
should not be withdrawn to do household chores or step in for a breadwinner when the household faces a crisis; that they should be encouraged to do homework. In addition, parents are unable to give them the help they may need at home to guide them in their homework. Actively involving parents and teachers to meet this challenge, designing the school curriculum and educational materials to transform school attendance into a joyful rather than alienating experience, holding teachers accountable for ensuring teaching standards within the classroom that do not necessitate additional private tuition, offering life skills which prepare children to participate in the wider society and economy: educational policy will clearly have to be thought about more imaginatively than is currently the case.

Finally, however, there is a need to consider the very real material constraints that lie behind the failure to send and keep children at school. As we have seen, it is the more vulnerable households, those headed by women or primarily reliant on earnings from casual labour, that are less likely than the rest of the population to send their children to school. While there are various NGOs active in our study neighbourhoods, and NGO membership is associated with higher likelihood of children attending school, the more vulnerable households are less likely to belong to an NGO. NGO membership appears to operate through building the asset base of low-income households rather than influencing values and aspirations, suggesting the importance of material pathways of change. Clearly, some form of basic safety net that tides households through periods of crisis could make an enormous difference to their capacity to keep their children at school. Given the significance of health-related expenditures as a major factor in perpetuating and exacerbating poverty, security of access to basic health services might allow parents to aspire to, and afford, education for their children.

\section{Notes}

1 An attempted rape at 3 o'clock in the afternoon close to where our interview was taking place brought home how real these fears were. An old man had entered a neighbouring house to rape a 12-year-old girl who had been left on her own while her mother went out to work. The

\section{Concluding comments}

Returning to the idea of continuities and transitions in intergenerational contracts within the family, it is clear from our findings that there are many more influences at work than our very simple framework allowed for. We did not investigate the affective dimension of these contracts but we are able to make a number of points about questions of personal agency and changing time horizons. We suggested people's sense of personal agency increased as far as family formation processes were concerned with the decline in child mortality and the greater availability of family planning. However, it is clear that sense of agency is also shaped by the larger context in which families find themselves and that many of those we interviewed did not feel that they had much control over their lives: this partly reflected the vulnerability of their own households as well as the endemic insecurity of the environment in which they lived. Questions of agency had a close bearing on their ability to think in terms of the future: as one harassed father put it, they did not have the 'space in their minds' to think about their children's current educational options and certainly none to plan for the future.

What was also missing in our analytical framework was any attention to the possibility of children exercising agency in shaping educational outcomes. Yet this was clearly a factor. Children's preferences were likely to be strongly influenced by parents' views but they were also shaped by the views and behaviour of their peers. Children's own interest in education as well as the example set by their peers played an important role in explaining which children stayed in school and which dropped out. Policies to address the intergenerational transmission of poverty through educational deficits will have to factor children's views and values into their design.

neighbours heard her screaming and came to her rescue. The men of the area paraded the old man through the neighbourhood to shame him. Our respondent said: 'You see, now you understand why we are so afraid for our daughters. But if that man had political connections, could anyone have done anything?' 


\section{References}

Becker, G. and Lewis, H.G. (1973) 'On the Interaction Between the Quantity and Quality of Children', Journal of Political Economy 81: S279-88

Chambers, R. (1989) 'Vulnerability, Coping and Policy', IDS Bulletin 20.2: 1-7

Cleland, J. and Wilson, C. (1987) 'Demand Theories of the Fertility Transition: An Iconoclastic View', Population Studies 41.1: 5-30

Desai, S. (1993) 'The Impact of Family Size on Children's Nutritional Status: Insights from a Comparative Perspective', in C.B. Lloyd (ed.), Fertility, Family Size and Structure: Consequences for Families and Children, New York: Population Council

Hamid, S. (1998) 'Comments', proceedings of international conference Poverty: Emerging Challenges, Bangladesh Institute of Development Studies, Dhaka

Hulme, D.; Moore, K. and Shepherd, A. (2001) Chronic Poverty: Meanings and Analytical Frameworks, CPRC Working Paper 2, Manchester: Institute of Development Policy Management, University of Manchester

Jesmin, S. and Salway, S. (2000) 'Marriage Among the Urban Poor of Bangladesh: Instability and Uncertainty', Journal of International Development 12.5: 689-705

Kabeer, N. (2003) 'Deprivation, Discrimination and Delivery: Competing Explanations for Child Labour and Educational Failure in South Asia', in N. Kabeer; G.B. Nambissan and R. Subrahmanian (eds), Child Labour and the Right to Education in South Asia: Needs Versus Rights.', New Delhi: Sage Publications

Kabeer, N. (2001) 'Intergenerational Contracts, Demographic Transitions and the
Quantity-Quality Trade-off: Children, Parents and Investing in the Future', Journal of International Development 12.4: 463-82

Kabeer, N. (1996) Gender, Demographic Transition and the Economics of Family Size, UNRISD Occasional Paper 7, Geneva: UN Research Institute for Social Development

Khan, I.A. (2001) 'Making the Urban Poor Stay in Town: Mobilising Social Capital Resources', Discourse 4.1, Dhaka: Institute for Development Policy Analysis and Advocacy and Proshika

Lloyd, C.B. (1994) Investing in the Next Generation: The Implications of High Fertility at the Level of the Family, Policy Research Division Working Papers 63, New York: Population Council

Lloyd, C.B. and Ivanov, S. (1988) 'The Effects of Improved Child Survival on Family Planning Practice and Fertility', Studies in Family Planning 19.3: 141-61

Montgomery, M. (1999) Mortality Decline and Demographic Response: Towards a New Agenda, Policy Research Division Working Papers 122, New York: Population Council

Montgomery. M.; Arends-Kuenning, M. and Mete, C. (1999) The Quantity-Quality Transition in Asia, Policy Research Division Working Papers 123, New York: Population Council

Scheper-Hughes, N. (1992) Death Without Weeping: The Violence of Everyday Life in Brazil, Berkeley: University of California Press

Stone, L. (1977) The Family, Sex and Marriage in England 1500-1800, London: Weidenfeld and Nicolson

Wood, G. and Salway, S. (2000) 'Securing Livelihoods in Dhaka Slums', Journal of International Development 12.5: 669-88 